\title{
EFFICIENCY OF FLEXURAL STRENGTHENING OF REINFORCED CONCRETE BEAMS BY NEAR SURFACE MOUNTED CARBON FIBER REINFORCEMENT POLYMER RODS AND EXTERNALLY BONDED SHEETS
}

\author{
*Wissam S. Abdullah ${ }^{1}$
}

Hassan F. Hassan ${ }^{1}$

1) Civil Engineering Department, College of Engineering, Mustansiriyah University, Baghdad, Iraq

\begin{abstract}
This study investigated the flexural behavior of reinforcement concrete beam strengthened with different techniques. The purpose of this research to study the various techniques of strengthening and knowing the effect of each technique on the beam behavior. Ten simply supported beams tested in this study. The total length of the beams and clear span were $1800 \mathrm{~mm}$ and $1650 \mathrm{~mm}$, respectively. The cross section was $(180 \times 250) \mathrm{mm}$. Tested beams were divided into two categories' the first category consist of one beams and considered as reference, while the second category consist of nine beams divided into Two groups according to the Strengthening techniques such as near surface mounted (NSM) and external bonded reinforcement (EBR).The experimental results showed improvement in ultimate load capacity for strengthened beams ranging from (6 to $89 \%$ ) for NSM and (31 to 96\%) for EBR and reduction in deflection for strengthened beams ranging from (6 to 43\%) as compared with reference beam. When the number and length of CFRP bars are increased, the number of cracks increase while the width of the cracks and the spacing decrease, and the same observation is made when the width of the CFRP sheet is increased. The experimental load capacities of strengthened beams were compared with the design provisions given by $\mathrm{ACl} 440.2 \mathrm{R}-17$ guideline for NSM and EBR technique and EC2 guideline for EBR technique, the average ratio (1.2 and 0.97 ) respectively, which showed that reasonable and a good agreement for all strengthened beams.
\end{abstract}

Keywords: Flexural performance, EBR, NSM, Deflection, Crack width, Strain, Ductility

\section{Introduction}

Traditional techniques have generally been used for the flexural strengthening of $\mathrm{RC}$ elements, such as overlaying, jacketing, external pre-stress and external bonding of steel plates. These methods suffer disadvantages from complicated implementation processes and lack of durability. The use of FRP composites to improve the flexural strength of existing structures has generally been accepted in recent years. The cost of materials, including fibers and resins, is higher than that of conventional materials, but the overall lifecycle cost would be lower due to lower installation costs, higher performance and lower maintenance costs [1-2]. Several experimental studies and practical applications have been carried out which have shown that strengthening effects can be reflected in a wide range of aspects, such as improving structural stiffness, load-bearing capacity, ductility and corrosion resistance[3].For the repair and reconstruction of various reinforced concrete structures, FRP is a widely used technology [4]. The mechanical properties of FRP are determined by the mechanical behavior of both

*Corresponding Author: wissam.samir90@gmail.com 
the fibers and the matrix, as well as their interaction [5]. EBR and NSM are the two main techniques developed for strengthening concrete structures using FRP. Mohammed [6] studied flexural behavior of RC beams strengthened with EBR-CFRP laminates. Nine RC beams ( $150 * 250 * 2000 \mathrm{~mm}$ total length). The first beam was used as a control specimen without strengthening while the other eight beams were strengthened by using CFRP laminates. The purpose of this study was to analyze the effect of number of CFRP layers (one and two layers were used), the shape and configuration of external anchorage and the length of CFRP strip. The test results showed that the external anchorages are very useful for increasing the link between the CFRP material and the concrete, as well as improving the structural behavior of the reinforced beams (increasing crack load, reducing the deflection, and increasing the ultimate load capacity). Husain et al.[7] studied the behavior of repaired and strengthened RC beams by CFRP sheet, fourteen simply supported RC beam subjected to two-point loads, once for strengthened and once for repair, identical beams were used to allow a comparison between them. All beams had the same dimensions $(160 * 240 * 2600 \mathrm{~mm}$ total length). The test results showed that the use of CFRP sheet for external strengthening improves crack pattern, ultimate load, and deflection significantly. The failure of strengthening beams was caused by steel yield followed by CFRP rupture. The increase of ultimate load for beams are externally strengthened by CFRP sheet based on the total area of CFRP sheet. N. Attari et al. [8] studied the behavior of RC beams reinforced in flexural with EB by using CFRP and/or GFRP sheets due to high ductility of GFRP and high strength of CFRP, seven simply supported RC beams $(160 * 100 \mathrm{~mm}$, $1500 \mathrm{~mm}$ total length). The first beam was used as a control specimen without strengthening. All the other six beams were strengthened by using FRP sheet were divided into two series depended on the fiber orientation (unidirectional or bidirectional). The test results showed that the use of twin layers carbon and glass sheets to strengthen RC beams was very effective. Also the test result show that the ultimate loads are equal when strengthened beams with carbon and glass sheet, this finding is quite important in terms of cost-efficiency. Louis et al. [9] studied the influence of using of the CFRP sheet on deflection, eight simply supported RC beams was used with total span length $(2000 \mathrm{~mm})$ and tested under one point load. One beam was used as a control specimen without strengthening. All the other seven beams were strengthened in the tension side with CFRP sheets. The total depths of beam were $(100,133,160$ and $200 \mathrm{~mm})$. All beams are reinforced with ( $\rho$ min) excluding two beams that have been reinforced with $(2 * \rho \min )$ and $(\rho \max )$. The test results showed that the use of the CFRP sheet has a significant effect on deflection by increasing the stiffness of the beam, especially beyond the pre cracking stage. The (Span/Depth) ratio had a significant impact on load-deflection response, with a decrease in the (Span/Depth) ratio resulting in a decrease in ultimate deflection and an increase in maximum load capacity. Teng et al. [10] studied the behavior of RC beams strengthened with different lengths of NSM -CFRP strips, five simply supported RC beam were used and tested under four point loads. The first beam was used as a control beam without strengthening; the other four beams were strengthened with different lengths of CFRP strips $(500,1200,1800$ and $2.900 \mathrm{~mm})$. The results show that the deboning failure was the primary mode of failure in all tested beams, with the exception of the beam with the longest embedment length. Also when comparison the 
results with the control beam, the beam with short-length strip had no increased strength. This could have been because the bonded length ended in the constant moment zone, which means the failure could have happened in the unstrengthen zone. El-Gamal, et al. [11] studied the behavior of RC beams strengthened in flexure with NSM technique using glass and carbon fiber, ten RC beams $(300 * 200 \mathrm{~mm}$, $2760 \mathrm{~mm}$ total length) was classified into two groups depended on the ratio of tension steel bar, the first group (seven beams) had two steel bars with a diameter of $12 \mathrm{~mm}$ on the bottom side and the second group (three beams) had four steel bars with a diameter of $12 \mathrm{~mm}$ on the bottom side. In the first group, one beam was held unstrengthen as a guide beam, two beams was strengthen with one or two $\phi 10 \mathrm{~mm}$ CFRP bars, two beams were strengthen with one or two $\phi 10 \mathrm{~mm}$ GFRP bar, the last two beams were strengthened with NSM and EBR (hybrid technique); one beam was strengthened with a CFRP sheet and a CFRP bar, the second was strengthened with a CFRP sheet and GFRP bar. The second group (three beams), one beam was held unstrengthen as a guide beam, the other two beams are strengthen with one or two CFRP bars. This study focused on studying effective of four parameters; the type of FRP used (carbon or glass), the system used NSM or Hybrid, the amount of FRP used, and the steel reinforcement ratio. The test result show that the hybrid technique provided limited benefit compared to the NSM technique, the NSMCFRP improved beams had higher ultimate capacities but less ductile behavior than the NSM-GFRP beams, the most common issue with NSM-CFRP bars was bonding failure. Hosen, et al. [12] studied the behavior of RC beams strengthened in flexure with NSM technique using steel and CFRP bars, six RC beams $(250 * 125$ and $2300 \mathrm{~mm}$ total length). One beam was held unstrengthen as a guide beam, four beams was strengthen with steel bars with different numbers (1 or 2) and diameters $(8,10,12$ and $16 \mathrm{~mm})$, the last beam was strengthened with CFRP bar $(12 \mathrm{~mm}$ diameter).The bonded length of NSM steel and carbon bars (1900) mm. The test result show that the NSM steel bar strengthening method is an expensive way to improve the flexural strength of RC beams, as compared to the control beam, the reinforced beams had finer cracks with closer spacing and a higher first crack load. El-shafiey, et al.[13] studied the behavior of RC beams strengthened in flexure using different techniques (two NSM CFRP strips (BF), externally bonded steel plate (BS) and layer of ultra-high performance strain hardening cementitious composite (BU)). Four reinforced concrete beams $(300 * 150 \mathrm{~mm}, 3000$ $\mathrm{mm}$ total length). One beam was held unstrengthen as a guide beam, three beams were strengthened, the first beam was strengthened with two NSM CFRP strips with cross section $1.2 * 10 \mathrm{~mm}(\mathrm{BF})$, the second with EB steel plate with cross section $1.3 * 135 \mathrm{~mm}$ with end anchored with six bolted at each end of diameter $10 \mathrm{~mm}$ (BS) and the last beam strengthened with layer of ultra-high performance strain hardening cementitious composite (UHP-SHCC) with cross section $(60 \times 150 \mathrm{~mm})(\mathrm{BU})$ techniques. All beams had two 12-mm steel bars at the bottom and two $(8 \mathrm{~mm})$ steel bar at the top. Stirrups diameter is $10 \mathrm{~mm}$ were spaced $100 \mathrm{~mm}$ for length equal to $1000 \mathrm{~mm}$ from right and left support, however the mid length $700 \mathrm{~mm}$, the stirrups were spaced at $230 \mathrm{~mm}$. The test result show that the greatest improvement in the yield load compared with the control beam was achieved by beam (BS), compared with control beam the ultimate load increased around $83 \%, 72 \%$ and $63 \%$ for beams (BF), (BS) and (BU) and the most convenient technique is near surface mounted CFRP reinforcement, since it improves ductility more 
than other reinforcement techniques under static loading. Hassan et al. (2020) [14] studied the behavior of RC beam by Glass-fiberreinforced polymer (GFRP) bars and strengthened by CFRP sheets. Ten simply supported GFRP reinforced concrete beams $(200 * 150 \mathrm{~mm}, 1900 \mathrm{~mm}$ total length) .The major variables were GFRP reinforcement ratio and number of CFRP sheets. Steel bars with a diameter of $(8 \mathrm{~mm})$ with spacing $(75 \mathrm{~mm})$ was used as shear reinforcement in all beams. The main parameters were GFRP reinforcement ratio and number of CFRP sheets. The result show that they concluded that the use of a twin -layer of CFRP sheets to strengthen GFRP-RC beams is very efficient, the max. $(\mathcal{E}$ cu $)$ was ranging between $(0.42 \%)$ to $(0.55 \%)$ respectively, these findings are higher than the standard values described by the ACIs which consider that for the specified concrete grades $\left(\mathcal{E}_{\mathrm{cu}}\right)$ is between $(0.3 \%)$ and $(0.35 \%)$.

\section{Experimental Work}

\subsection{Test Specimens}

Ten simply supported beams were constructed. The beams had a rectangular cross section of $180 \mathrm{~mm} * 250 \mathrm{~mm}, 1800 \mathrm{~mm}$ total length, and a clear span of $1650 \mathrm{~mm}$. All beams were reinforced with three $8 \mathrm{~mm}$ diameter deformed steel bars in the tension side and two $4 \mathrm{~mm}$ diameter deformed steel bars in the compression side. In order to avoid shear failure, all beams were reinforced with closed stirrups of $8 \mathrm{~mm}$ diameter deformed steel bars spaced at $70 \mathrm{~mm}$. The thickness of concrete cover was $30 \mathrm{~mm}$. The dimensions and reinforcement details of all test specimens as shown in Figure (1).

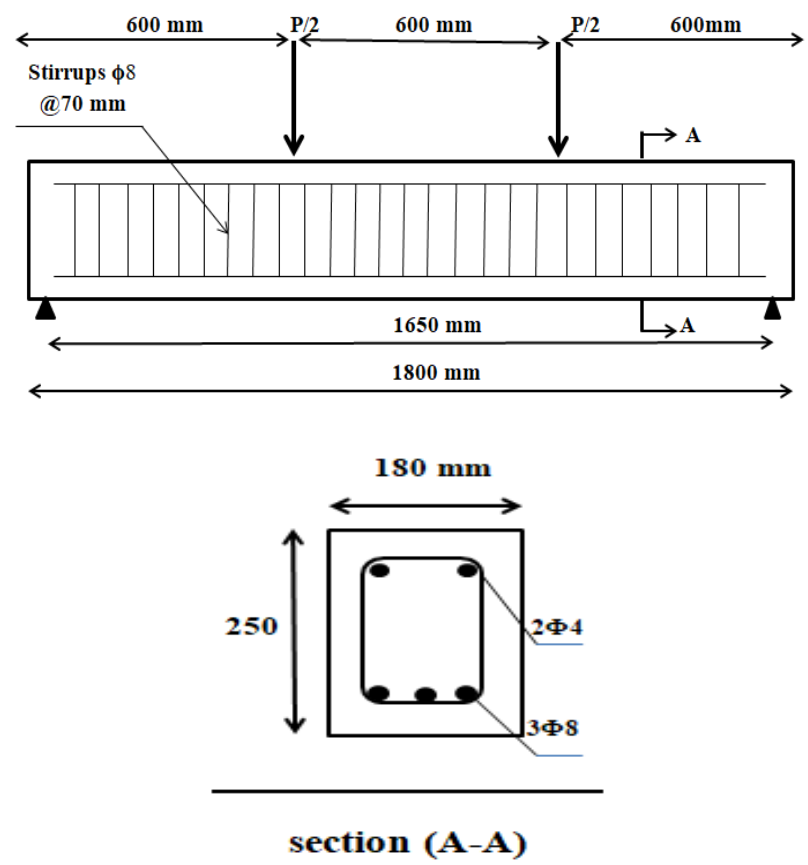

Figure 1. The dimensions and reinforcement details of test specimens

\subsection{Materials}

\subsubsection{Concrete}

Normal concrete mix is made with 28days targeted compressive strength of (35MPa). Details of the mix as shown in Table (1). Mixing the materials with using the horizontal rotary mixer has capacity $0.2 \mathrm{~m} 3$ available in the Structures laboratory, Al-Mustansiriyah University. The average compressive strength of the three concrete cylinders $(300 * 150) \mathrm{mm}$ was 36.8 $\mathrm{MPa}$ in according to ASTM C39 [15]. The rupture test module with a cross section of $(100 * 100) \mathrm{mm}$ and a total length of $500 \mathrm{~mm}$ was $3.86 \mathrm{MPa}$ average value of three concrete prisms in compliance with ASTM C78-02[16]. The splitting tensile strength test with a cross section of $(200 * 100) \mathrm{mm}$ was $3.2 \mathrm{MPa}$ average value of three concrete cylinders in according to ASTMC496 / C496M-11[17]. 
Table 1. Mixture design characteristics

\begin{tabular}{ccccc}
\hline $\begin{array}{c}\text { Concrete } \\
\text { strength (MPa) }\end{array}$ & $\begin{array}{c}\text { Cement } \\
(\mathrm{kg} / \mathrm{m} 3)\end{array}$ & $\begin{array}{c}\text { Sand } \\
(\mathrm{kg} / \mathrm{m} 3)\end{array}$ & $\begin{array}{c}\text { Gravel } \\
(\mathbf{k g} / \mathrm{m} 3)\end{array}$ & W/C \\
35 & 450 & 550 & 1000 & 0.4 \\
\hline
\end{tabular}

\subsubsection{Steel and CFRP Reinforcement}

Deformed steel bars with a diameter of 8 and 4 $\mathrm{mm}$ were used for all beams as top and bottom, respectively. The yield strengths of the steel bars with diameters of 8 and $4 \mathrm{~mm}$ were 460 and $395 \mathrm{MPa}$, respectively. Shear reinforcement was also provided by deformed steel bars with a diameter of $8 \mathrm{~mm}$. For strengthening, CFRP bars of $6 \mathrm{~mm}$ and $10 \mathrm{~mm}$ diameter were used as NSM reinforcement materials. As an EBR, CFRP sheets with a unidirectional woven carbon fiber fabric with a thickness of $0.17 \mathrm{~mm}$ were used. The mechanical properties of CFRP as shown in Table (2).

Table 2. Mechanical properties of CFRP*

\begin{tabular}{lccc}
\hline Properties & CFRP bar & CFRP bar & $\begin{array}{c}\text { CFRP } \\
\text { sheet }\end{array}$ \\
\hline Diameter(mm) & 6 & 10 & - \\
$\begin{array}{l}\text { Tensile } \\
\text { strength(MPA) }\end{array}$ & 2241 & 2172 & 4900 \\
$\begin{array}{l}\text { E-modulus ( } \\
\text { GPa ) }\end{array}$ & 124 & 124 & 230 \\
$\begin{array}{l}\text { Width (mm) } \\
\text { Thickness (mm) }\end{array}$ & - & - & 500 \\
\hline
\end{tabular}

*According to the manufacture company

\subsubsection{Bonding Material}

Sikadur@330 was used to bond the CFRP (sheet and bar) with concrete. The manufacturing specification provides all of the properties of material as shown in Table (3).
Table 3. Adhesive materials' technical properties*

\begin{tabular}{|c|c|c|c|c|c|c|}
\hline 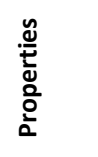 & 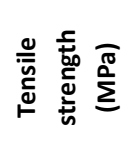 & 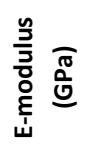 & 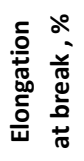 & 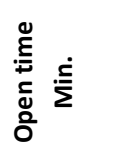 & 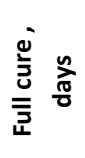 & 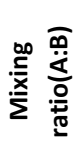 \\
\hline Sikad & 30 & 4.5 & 0.9 & 30 & 7 & 1:4 \\
\hline$u^{\oplus}{ }^{\circledR 3}$ & & & & $(a t+35 C$ & & \\
\hline 0 & & & & o) & & \\
\hline
\end{tabular}

*According to the manufacture company

\subsection{Test Measurements and Instrumentation}

\subsubsection{Load Measurement}

The beams are tested in the Structures laboratory, Al-Mustansiriyah University by a universal testing machine of $3000 \mathrm{KN}$ maximum capacity.

\subsubsection{Deflection Measurement}

Vertical deflection has been measured by using a mechanical dial gauge of $(0.01 \mathrm{~mm})$ accuracy. The gage is placed at the mid span of tested beams.

\subsubsection{Strain Gauges}

Strain gauges are installed on the bottom of tension longitudinal steel reinforcement at the mid span of tested beam to measure their strain during loading. Electrical strain gauges with (5) mm gauge length.

\subsection{Test Arrangement and Specimens Details}

Two points load was used to test the efficiency of flexural of RC beams strengthened by CFRP bar and sheet. Ten simply support beams were used in this study. Nine of them were strengthened by CFRP bar and sheet. These beams divided to two groups. The first group consist of six beams strengthened by NSMCFRP bar inserted into grooves, three of them (N1-6-165, N2-6-165 and N3-6-165) had different number (1,2 and 3) of CFRP bar $\phi 6$ $\mathrm{mm}$ with the same length $1650 \mathrm{~mm}$ inserted into grooves $(10 * 10 \mathrm{~mm})$ according to the 
number of CFRP bar and the others three beams of the first group (N1-10-60,N1-10-90 and N1-10-165) had one CFRP bar $\phi 10 \mathrm{~mm}$ with different length of CFRP bar $(600,900$ and $1650 \mathrm{~mm})$ inserted into one groove $\left(15^{*} 15 \mathrm{~mm}\right)$ for example, code (N2- 6-165) indicates that the beam is strengthened by near surface mounted technique by using two CFRP bars of nominal diameter $6 \mathrm{~mm}$ inserted in two grooves in tension side and $1650 \mathrm{~mm}$ length of each bar.

The second group consist of three beams strengthened by CFRP sheet with different techniques with the same total CFRP area installed to the tension face,(ESL) beam was strengthened by two strips $50 \mathrm{~mm}$ width of each strip and $1650 \mathrm{~mm}$ length with L-shape anchorages $(150 \mathrm{~mm}$ length and $40 \mathrm{~mm}$ width the clear distance between them $120 \mathrm{~mm}$ facing each other on both sides along the strips),(EGU) beam was strengthened by sheet $150 \mathrm{~mm}$ width and $1650 \mathrm{~mm}$ length insert in two grooves $(10 * 10 \mathrm{~mm})$ to become the net width $110 \mathrm{~mm}$ with U-Warp at ends,(EFF) beam was strengthened by one sheet $130 \mathrm{~mm}$ width and $1650 \mathrm{~mm}$ length and fully warp at ends and one beam was kept unstrengthen used as reference beam(RB). Table (4) and Figure (2) shows the details of the tested beams.

Table 4. Coding and details of tested specimens

\begin{tabular}{cccccc}
\hline Specimen & $\begin{array}{c}\text { Strength } \\
\text { system }\end{array}$ & $\begin{array}{c}\text { No. of } \\
\text { CFRP } \\
\text { bar or } \\
\text { sheet }\end{array}$ & $\begin{array}{c}\text { Dia. } \\
\text { of } \\
\text { CFRP } \\
\text { bar } \\
(\mathbf{m m})\end{array}$ & $\begin{array}{c}\text { Widt } \\
\text { h of } \\
\text { sheet } \\
(\mathbf{m m})\end{array}$ & $\begin{array}{c}\text { Length } \\
\text { of sheet } \\
\text { or bar } \\
(\mathbf{m m})\end{array}$ \\
\hline RB & $\begin{array}{c}\text { Reference } \\
\text { beam }\end{array}$ & - & - & - & - \\
\hline N1-6-165 & & 1 & 6 & - & 1650 \\
N2-6-165 & & 2 & 6 & - & 1650 \\
N3-6-165 & NSM & 3 & 6 & - & 1650 \\
N1-10-60 & CFRP bar & 1 & 10 & - & 600 \\
N1-10-90 & & 1 & 10 & - & 900
\end{tabular}

\begin{tabular}{cccccc}
$\begin{array}{c}\text { N1-10- } \\
165\end{array}$ & & 1 & 10 & - & 1650 \\
\hline ESL & EBR & 2 & - & 50 & 1650 \\
EGU & CFRP sheet & 1 & - & 110 & 1650 \\
EFF & & 1 & & & \\
& & 1 & - & 130 & 1650
\end{tabular}

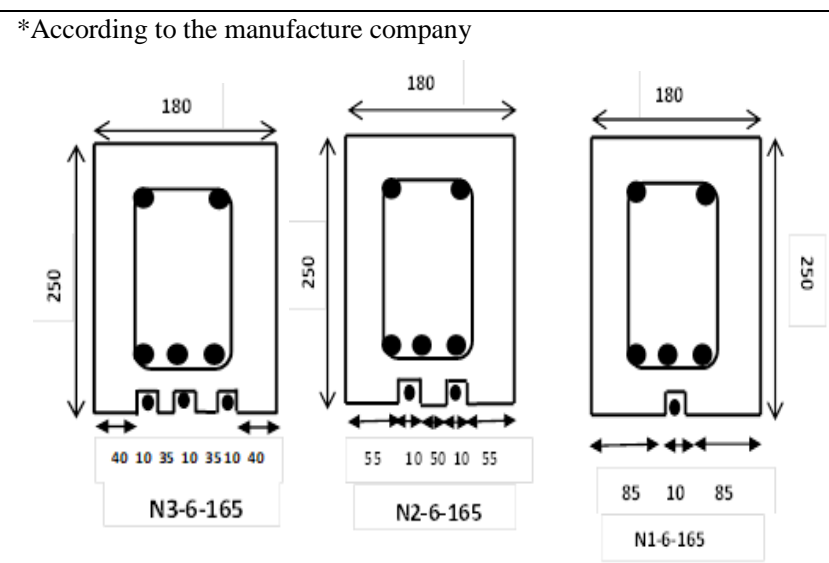

NSM with CFRP bar $\phi 6 \mathrm{~mm}$

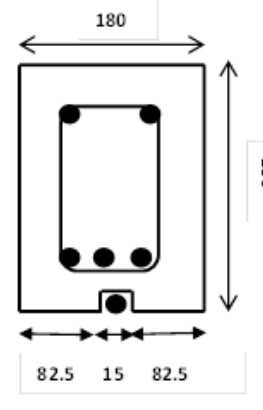

$-a-$

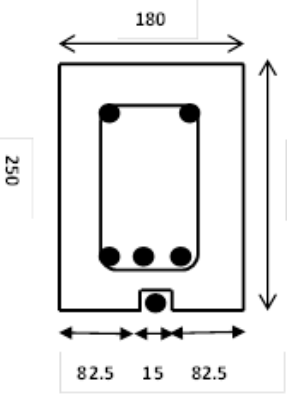

$-b-$

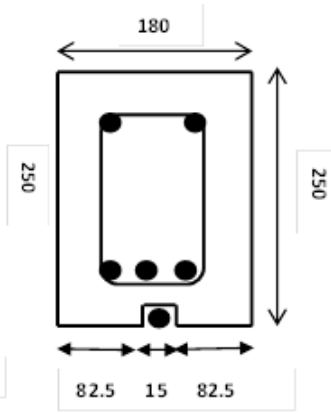

$-c-$
NSM with CFRP bar $\phi 10 \mathrm{~mm}$ (a-CFRP bar length 600 $\mathrm{mm}, \mathrm{b}$ - CFRP bar length $900 \mathrm{~mm}, \mathrm{c}-\mathrm{CFRP}$ bar length $1650 \mathrm{~mm})$
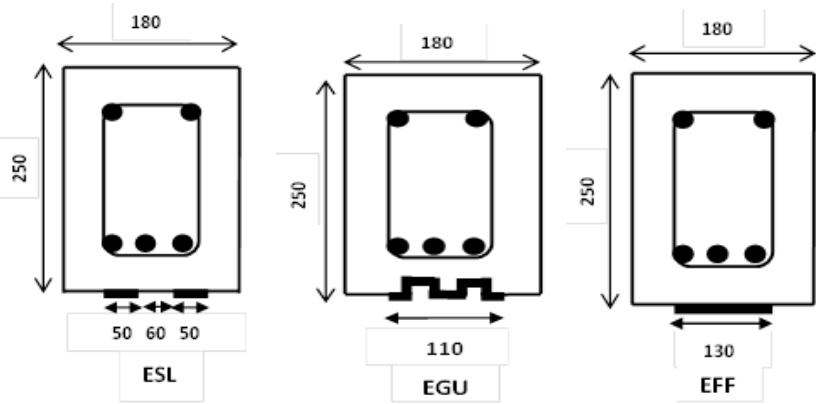

EBR with CFRP sheet

Figure 2. Details of tested beams

\subsubsection{FRP System Application}

For EBR, the CFRP sheet was cut into the required dimensions and after concrete surface preparation and making sure clean; type A and 
type B epoxy had been mixed to the recommended ratio by the manufacturer. The epoxy was applied to the beam's surfaces as well. After the CFRP sheet had been applied to the concrete surface, a piece of rubber was used to squeeze out the excess epoxy and to remove the entrapped air. The rubber was passed over CFRP sheet in the direction of the fibers to avoid any distortion to the fiber orientation. For NSM, after removing the wooden rules from groove and making sure clean from dust and dry, the groove was filled with the epoxy, then the CFRP bar was inserted into the groove and was gently pushed to force the epoxy to pass between the CFRP bar and the groove sides. In the end, excess epoxy was removed and the surface was levelled.

\section{Test Results and Discussion}

The objective of this research is to investigate the effects of CFRP in improvement the flexural behavior of reinforced concrete beams. Test results were evaluated based on failure load, mode of failure, strain, cracking behavior, mid span deflection and ductility.

\subsection{Load - Deflection Performance}

Figures (3-6), shows the load-deflection curves for all tested beams. Dial gauge was installed at the mid span of beams to read the maximum deflection. The results show that the deflections of strengthened beams showed acceptable decrease in the deflection as compared with reference beam at same load level expect the beams which strengthened by 60 and $90 \mathrm{~cm}$ of CFRP bar showed marginal decrease in the deflection compared with reference beam. Table (5) shown the results for all beams experiments.

\subsubsection{Number, Length and Diameter of CFRP bar Influence on Ultimate Loads}

The effect of increasing in the number of CFRP bar showed in tested beams (N1-6-165, N2-6-
165 and N3-6-165), the result showed that increase in the ultimate load capacity was about (44, 63 and 89\%), respectively, as compared with RB. While the effect of increasing in the length of CFRP bar showed in tested beams (N1-10-60, N1-10-90 and N1-10-165), the results show that increase in the ultimate load capacity was about (6, 21 and 75\%), respectively, as compared with $\mathrm{RB}$. The effect of increasing in the diameter of CFRP bar showed in tested beams(N3-6-165 and N1-10$165)$ which have approximately same total area of CFRP bar, the result show that increase in the ultimate load capacity was about (89 and 75\%), respectively, as compared with $\mathrm{RB}$.

Table 5. Test Results of tested beams

\begin{tabular}{|c|c|c|c|c|c|}
\hline $\begin{array}{c}\text { Beam } \\
\text { Sample }\end{array}$ & $\begin{array}{l}\text { Pcr } \\
(\mathrm{KN})\end{array}$ & $\begin{array}{c}\mathbf{P u} \\
(\mathbf{K N})\end{array}$ & $\begin{array}{c}\text { increase } \\
\text { percentage } \\
\%\end{array}$ & $\begin{array}{c}\text { Mid span } \\
\text { deflection } \\
(\mathrm{mm})\end{array}$ & $\begin{array}{c}\text { Mode } \\
\text { of } \\
\text { failure }\end{array}$ \\
\hline $\mathrm{RB}$ & 26 & 67.5 & - & 4.2 & FF \\
\hline $\begin{array}{l}\text { N1-6- } \\
165\end{array}$ & 27.5 & 97.5 & 44 & 8.3 & SY-FF \\
\hline $\begin{array}{l}\text { N2-6- } \\
165\end{array}$ & 28.5 & 110 & 63 & 9.65 & SY-FF \\
\hline $\begin{array}{c}\text { N3-6- } \\
165 \\
\end{array}$ & 34.5 & 127.5 & 89 & 10.9 & SY-DF \\
\hline $\begin{array}{c}\text { N1-10- } \\
60\end{array}$ & 27 & 71.5 & 6 & 4.1 & SY-CC \\
\hline $\begin{array}{l}\text { N1-10- } \\
90\end{array}$ & 28 & 81.5 & 21 & 5.9 & SY-CC \\
\hline $\begin{array}{c}\text { N1-10- } \\
165 \\
\end{array}$ & 30 & 118 & 75 & 10.5 & SY-DF \\
\hline ESL & 28 & 88.5 & 31 & 5.3 & $\begin{array}{l}\text { SY- } \\
\text { DEB }\end{array}$ \\
\hline EGU & 33 & 120 & 78 & 6.4 & $\begin{array}{l}\text { SY- } \\
\text { RUP }\end{array}$ \\
\hline EFF & 34.5 & 132.5 & 96 & 7.3 & $\begin{array}{l}\text { SY- } \\
\text { DEB }\end{array}$ \\
\hline
\end{tabular}

$*_{\mathrm{FF}}$ : flexural failure, SY: steel yielding, CC: crushing concrete, DF: delamination failure, DEB: debonding of CFRP sheet, RUP: Rupture of CFRP sheet.

\subsubsection{Effects of Different Techniques of EBR by CFRP Sheet on Failure Load}

To study the effect of CFRP sheet, three different techniques (ESL, EGU and EFF ) are used for strengthening beams with the same total area of CFRP sheet $\left(2973 \mathrm{~cm}^{2}\right)$, the result show that increase in the ultimate load capacity 
was about (31 , 78 and 96\%), respectively, compared with RB.The results showed that the ultimate load of strengthened beams showed significantly increase in the load capacity compared with reference beam at same load of failure expect the beams which strengthened by short length of CFRP bar showed marginal increase in the load capacity compared with reference beam. Also the result of beams (N3-6165 and N1-10-165) show that the increase in load capacity is considered to be close between them, so it is favorable to use a large diameter with less CFRP bar to reduce the overall cost of reinforcement by reducing the cost of CFRP bar, the amount of resin and the time and effort involved.

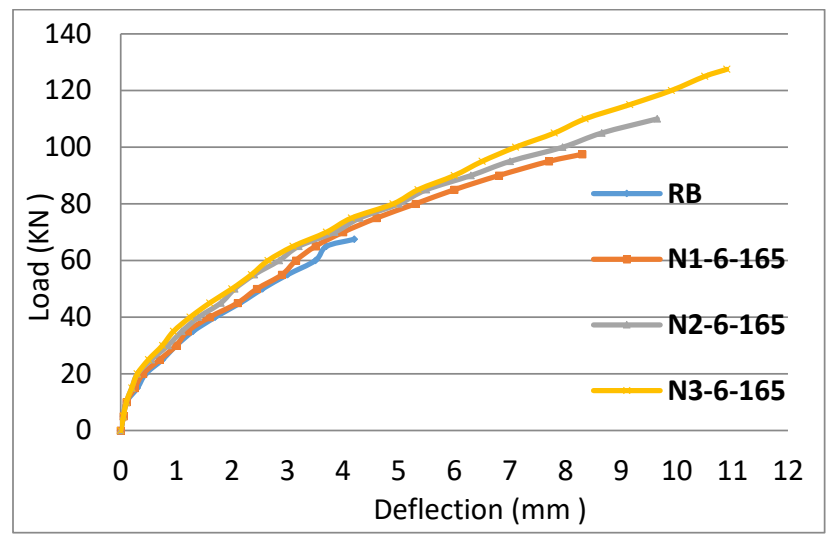

Figure 3. Load - Deflection of beams with NSM CFRP bar $\phi 6$

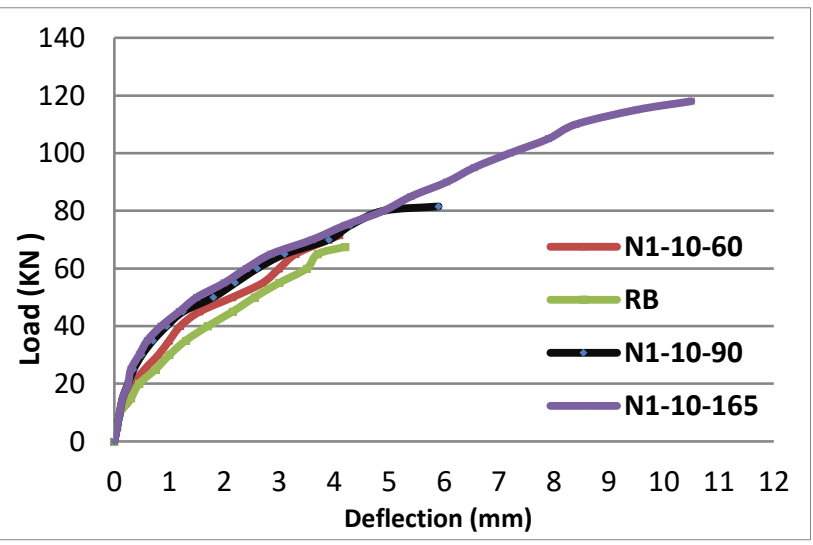

Figure 4. Load - Deflection of beams with NSM CFRP bar $\phi 10$

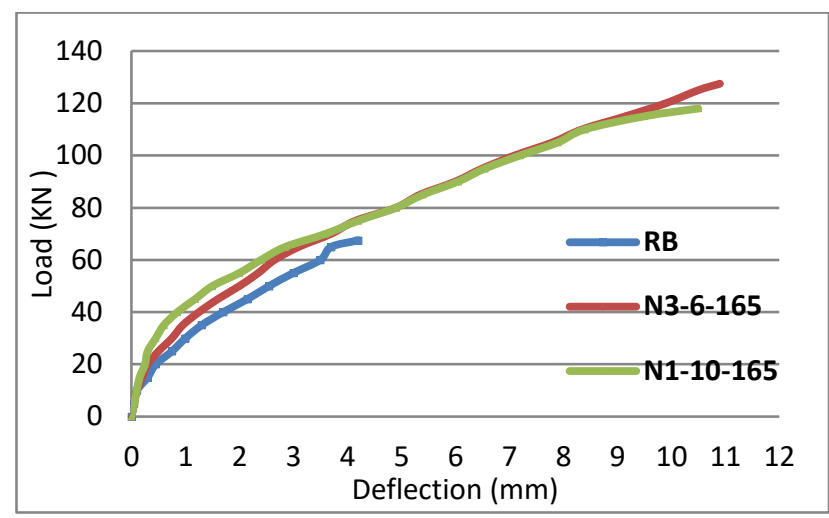

Figure 5. Load -Deflection of beams with same area of CFRP bar

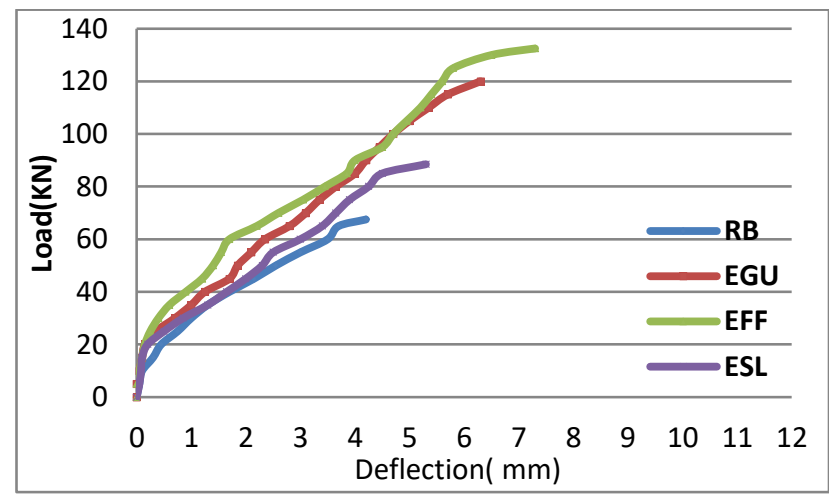

Figure 6. Load - Deflection of beams with EBR CFRP sheet

\subsection{Steel Strain}

Figures (7-9) shows the load-steel strain relationship for all tested beams. The effects of increase the number of CFRP bar leads to decrease the steel strain at the same load level of beam N1-6-165 $(\mathrm{P}=97.5 \mathrm{KN})$, the strain in steel bars of beams (N2-6-165 and N3-6-165) was decreased by (5 and $9 \%$ ),respectively. The effects of increase the length of CFRP bar leads to decrease the steel strain at the same load level of beam N1-10-60 $(\mathrm{P}=71.5 \mathrm{KN})$, the strain in steel bars of beams (N1-10-90 and N1-10-165) was decreased by ( 8 and $20 \%$ ),respectively .And the effects of increase the width of CFRP sheet leads to decrease the strain in steel bars at the same load level of beam ESL $(\mathrm{P}=88.5 \mathrm{KN})$, the strain in steel bars of beams (EGU and EFF) was decreased by (34 and $86 \%$ ), respectively. 


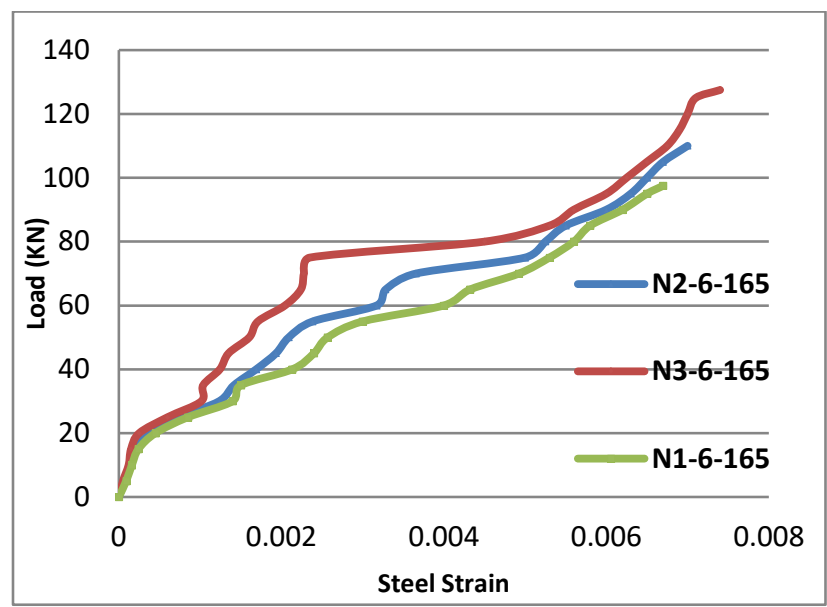

Figure 7. Load -steel strain of beams with NSM CFRP bar $\phi 6$

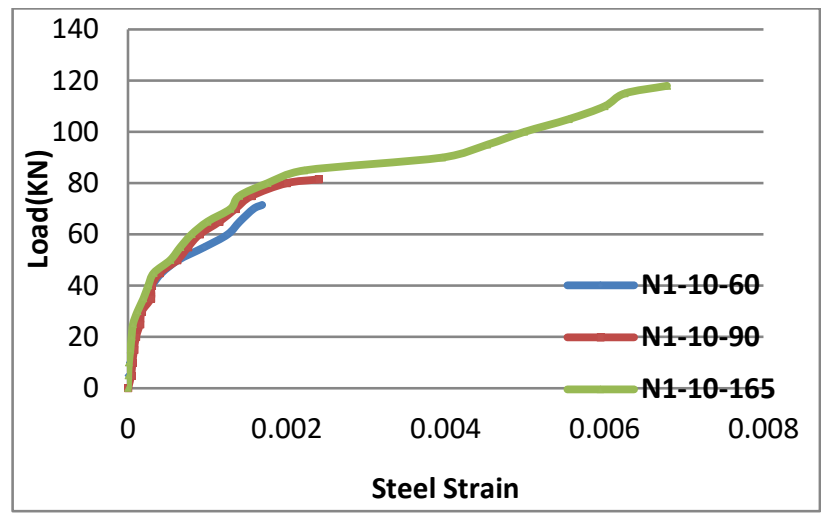

Figure 8. Load -steel strain of beams with NSM CFRP bar $\phi 10$

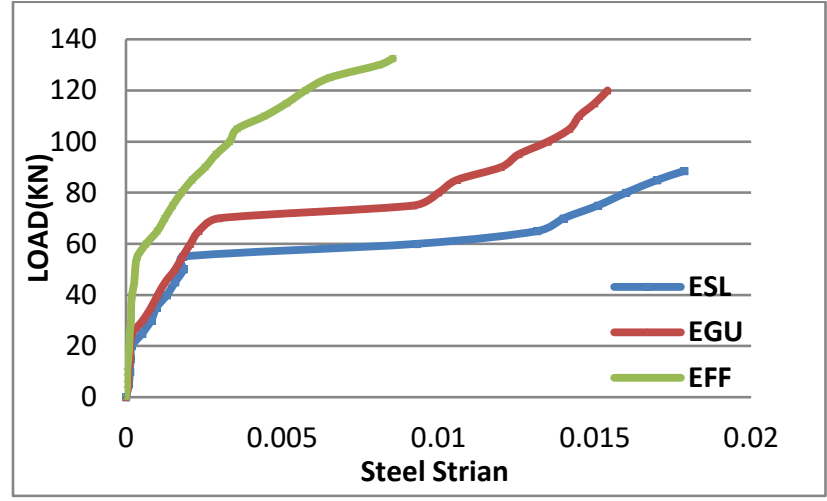

Figure 9. Load -steel strain relationship of beams with EBR CFRP sheet

\subsection{Crack width}

By Using Photoshop Creative Cloud software, the crack width and spacing are determined using analyzed image where a real scale object reference is positioned and then the captured image is analyzed with a high accuracy for crack width prediction and spacing. The effect of strengthening on crack widths can be seen in Figures $(10$ - 12). The figures show that the increasing in CFRP bar and width of sheet leads to significant decrease in crack width expect the beams strengthened with short length of CFRP bar show marginal decrease in crack width compared with RB. At load $(67.5 \mathrm{KN})$ the maximum crack width was $3 \mathrm{~mm}, 1.42 \mathrm{~mm}, 0.38$ $\mathrm{mm}, 0.3 \mathrm{~mm}$ for the beams RB, N1-6-165, N26-165 and N3-6-165,respectively. This means when increasing the amount of CFRP bar lead to decrease the maximum crack width by about $52 \%, 87 \%$ and $90 \%$ respectively, compared to the reference beam. Similar observations were recorded for others strengthened beams. Table (6) shown the result of all tested beams.

Table 6. Crack width

\begin{tabular}{|c|c|c|c|c|c|}
\hline $\begin{array}{c}\text { Specime } \\
n\end{array}$ & $\begin{array}{c}\mathrm{Pu} \\
(\mathrm{KN})\end{array}$ & $\begin{array}{c}\text { Crack } \\
\text { width at } \\
\mathrm{Pu} \\
(\mathrm{mm})\end{array}$ & $\begin{array}{c}\text { Compa } \\
\text { red } \\
\text { load }\end{array}$ & $\begin{array}{c}\text { Crack } \\
\text { width at } \\
\text { Compared } \\
\text { Load } \\
(\mathrm{mm})\end{array}$ & $\begin{array}{c}\text { percentage } \\
\text { of decrease } \\
\qquad \%)\end{array}$ \\
\hline $\mathrm{RB}$ & 67.5 & 3 & 67.5 & 3 & $0 \%$ \\
\hline $\begin{array}{c}\text { N1-6- } \\
165\end{array}$ & 97.5 & 1.92 & & 1.42 & $52 \%$ \\
\hline $\begin{array}{c}\text { N2-6- } \\
165\end{array}$ & 110 & 1.48 & 67.5 & 0.38 & $87 \%$ \\
\hline $\begin{array}{c}\text { N3-6- } \\
165\end{array}$ & $\begin{array}{c}127 . \\
5\end{array}$ & 1.15 & & 0.3 & $90 \%$ \\
\hline $\begin{array}{c}\text { N1-10- } \\
60\end{array}$ & 71.5 & 2.9 & & 2.7 & $10 \%$ \\
\hline $\begin{array}{c}\text { N1-10- } \\
90\end{array}$ & 81.5 & 2.7 & 67.5 & 2.35 & $21.6 \%$ \\
\hline $\begin{array}{c}\text { N1-10- } \\
165\end{array}$ & 118 & 1.53 & & 0.5 & $83 \%$ \\
\hline ESL & 88.5 & 1.85 & & 1.35 & $55 \%$ \\
\hline EGU & 120 & 1.5 & 67.5 & 0.8 & $73 \%$ \\
\hline $\mathrm{EFF}$ & $\begin{array}{c}132 . \\
5\end{array}$ & 0.77 & & 0.228 & $92 \%$ \\
\hline
\end{tabular}




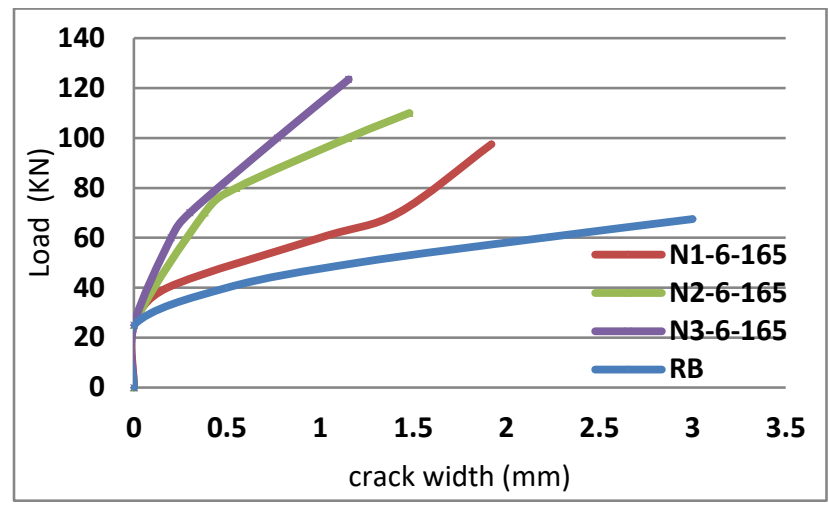

Figure 10. Load- experimental crack width of beams with NSM CFRP bar $\phi 6$

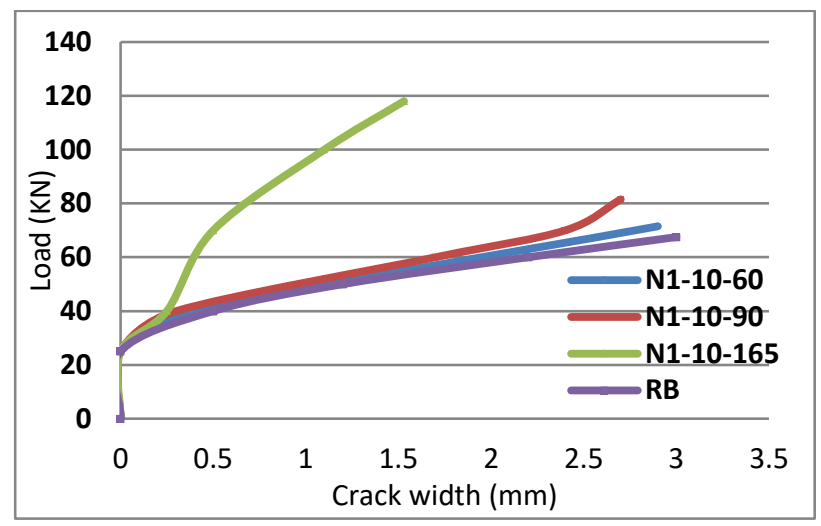

Figure 11. Load- experimental crack width of beams with NSM CFRP bar $\phi 10$

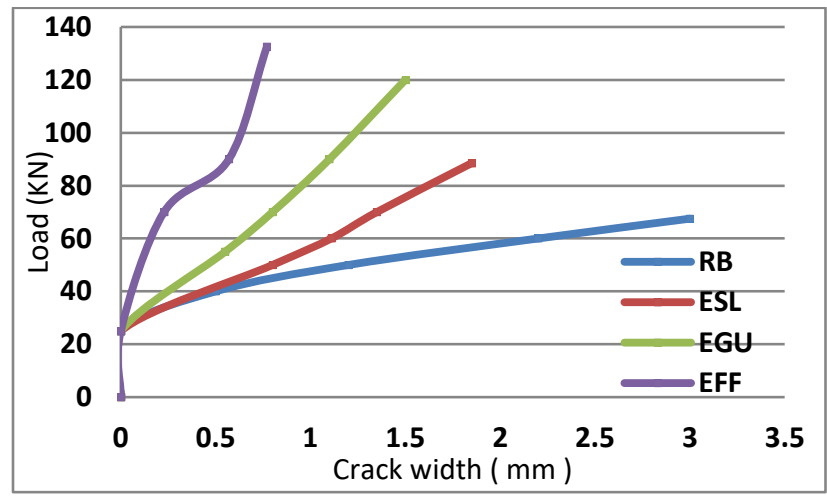

Figure 12. Load - experimental crack width of beams with EBR CFRP sheet

\subsection{Number and cracks spacing}

Table (7) shown the effect of strengthening on number and spacing of cracks. The result show that the strengthening by NSM and EBR lead to increase in the number of cracks and decrease cracks spacing as compared with reference beam expect the beams which strengthened with short length of CFRP due to inefficient strengthening length. These measurements of experimental crack space comparted with Euro code (EC2) [18] and (Ceroni) [19] for EBR, the results were close between experimental and calculated crack space. The calculated average spacing between cracks according to the equations of the mentioned above as follows:

$S_{r m}=\frac{2 f_{c t m} A_{c \cdot e f f} \xi_{b} E_{f} A_{f}}{\tau_{f m} u_{s}\left(E_{S} A_{s}+\xi_{b} E_{f} A_{f}\right)}$

$\mathrm{EC} 2$

where $A_{c, \text { eff }}$ is the effective area in tension taken as the lower of $2.5(\mathrm{~h}-\mathrm{d}) \mathrm{b}$ and $(\mathrm{h}-\mathrm{x}) \mathrm{b} / 3, \tau_{\mathrm{sm}}=$ $1.8 \mathrm{f}_{\mathrm{ctm}}$ and $\tau_{\mathrm{fm}}=1.25 \mathrm{f}_{\mathrm{ctm}}$ is the mean bond stress of the steel and the FRP, us and $\mathrm{u}_{\mathrm{f}}$ is the bond perimeter of the steel and FRP reinforcement and $\xi_{\mathrm{b}}$ is a bond parameter given as:

$\xi_{b}=\frac{\tau_{f m} E_{s} d_{s}}{\tau_{s m} E_{f} t_{f}}$

Where ds is the diameter of the steel bars and $t_{f}$ is thickness of the FRP.

$$
S_{r m}=S_{O}+\frac{k A_{c \cdot e f f}^{\gamma} \emptyset^{\alpha}}{A_{S}^{\delta}+\left(\frac{A_{f} E_{f}}{E_{S}}\right)^{\beta}}
$$

Ceroni

Table7. Number and crack spacing

\begin{tabular}{cccccc}
\hline Specimen & $\begin{array}{c}\text { NO. } \\
\text { of } \\
\text { crack }\end{array}$ & $\begin{array}{c}\text { Max. } \\
\text { crack } \\
\text { width } \\
(\mathrm{mm})\end{array}$ & $\begin{array}{c}\text { S } \\
\text { average } \\
\text { exp. } \\
\text { (cm) }\end{array}$ & $\begin{array}{c}\text { S. } \\
\text { average } \\
\text { EC14 }\end{array}$ & $\begin{array}{c}\text { S. } \\
\text { average } \\
\text { Ceroni } \\
{[15]}\end{array}$ \\
\hline RB & 5 & 3 & 13.57 & - & - \\
\hline N1-6-165 & 6 & 1.92 & 11.21 & - & - \\
N2-6-165 & 8 & 1.48 & 11.04 & - & - \\
N3-6-165 & 10 & 1.15 & 10.71 & - & - \\
\hline N1-10-60 & 4 & 2.9 & 25.4 & - & - \\
N1-10-90 & 5 & 2.7 & 18.77 & - & - \\
N1-10-165 & 9 & 1.53 & 10.5 & - & - \\
\hline ESL & 6 & 1.85 & 12 & 10 & 9.06 \\
EGU & 9 & 1.5 & 9.4 & 9.6 & 9 \\
EFF & 9 & 0.77 & 9.1 & 8.83 & 8.8 \\
\hline
\end{tabular}


The results show that when increasing the number and length of CFRP bars in NSM strengthening leads to reduce the crack width and spacing between cracks at all load level, also leads to increase the number of cracks after failure of beams and the same observation when the width of CFRP sheet increase in EBR strengthening.

\subsection{Ductility}

The ductility were calculated in this study by using two methods. The first method is conventional method is generally identified as a ratio of rotation $(\theta)$, curvature, or deflection $(\Delta)$ at failure to the corresponding property at yield. Deflection was used as the measurement of ductility in this study. The second method called energy method is used to estimate ductility of $\mathrm{RC}$ beams strengthened by CFRP materials was proposed by Oudah and El-Hacha (2012) [20] and can be calculated according to the equation as follow:

$\mu_{E}=\frac{\Delta \mathrm{u}}{\Delta \mathrm{y}} \quad$ Conventional method

$\mu_{E}=\frac{\mathrm{s}[\mathrm{Py}(\Delta \mathrm{u}-\Delta \mathrm{c})+\mathrm{Pu}(\Delta \mathrm{u}-\Delta \mathrm{y})+\mathrm{Pc} \Delta \mathrm{y}]}{\mathrm{Pu}^{2}} \quad$ El-Hacha

Where $\left(\mu_{\mathrm{E}}\right)$ is energy ductility index, $(\Delta \mathrm{u})$ is the ultimate deflection, $\mathrm{mm},(\Delta \mathrm{c})$ the cracking deflection, $\mathrm{mm},((\Delta \mathrm{y})$ is the yielding deflection, $\mathrm{mm},(\mathrm{Pc})$ is the cracking load, $\mathrm{KN},(\mathrm{Py})$ is the yielding load, $\mathrm{KN}$ and $(\mathrm{S})$ is the Slope of the line separating the elastic energy from the inelastic energy. Table (8) show the results of ductility index of all tested beams. The results show that the ductility index by conventional method and energy method decrease with the increase of the CFRP strengthening ratio. The results of the ductility index calculated by conventional method and energy method show decrease with the increase of the CFRP strengthening ratio along the clear span.
Table 8. Ductility index

\begin{tabular}{lccccccc}
\hline Specimen & $\mathrm{Pu}$ & $\Delta \mathrm{u}$ & $\mathrm{Pc}$ & $\Delta \mathrm{c.}$ & $\begin{array}{c}\Delta \\
\mathrm{y}\end{array}$ & $\begin{array}{c}\text { Deflection } \\
\text { ductility } \\
\text { index }\end{array}$ & $\begin{array}{c}\text { Energy } \\
\text { ductility } \\
\text { index }\end{array}$ \\
\hline RB & 67.5 & 4.2 & 26 & - & - & - & - \\
\hline N1-6- & 97.5 & 8.3 & 27.5 & 0.85 & 2 & 3.95 & 1.89 \\
N2-6- & 110 & 9.65 & 28.5 & 0.76 & 2 & 3.38 & 1.69 \\
N3-6- & 127.5 & 10.9 & 34.5 & 0.95 & 4 & 2.22 & 1.22 \\
\hline N1-10- & 71.5 & 4.1 & 27 & 0.4 & 3 & 1.05 & 1.02 \\
N1-10- & 81.5 & 5.9 & 28 & 0.44 & 5 & 1.156 & 1.11 \\
N1-10- & 118 & 10.5 & 30 & 0.45 & 5 & 1.94 & 1.29 \\
\hline ESL & 88.5 & 5.3 & 28 & 0.71 & 2 & 2.4 & 1.06 \\
EGU & 120 & 6.4 & 33 & 0.88 & 2 & 2.28 & 1.02 \\
EFF & 132.5 & 7.3 & 34.5 & 0.58 & 3 & 1.89 & 1.01 \\
\hline
\end{tabular}

\subsection{Theoretical Prediction of ultimate load}

To verify the validity of these formulas, the theoretical ultimate load capacity of CFRPstrengthened beams was calculated using the formulas given by EC2 [18] for EBR and ACI 440.2R-17[18] for NSM and EBR. The experimental and calculated results of ultimate load capability as shown in Table (9), the flexural strengthening of beams is well agreed upon by the calculation equations provided by EC2 [18] and ACI 440.2R-17 [21].

Table 9. Experimental and calculated results of ultimate load

\begin{tabular}{|c|c|c|c|c|c|}
\hline \multicolumn{6}{|c|}{ capacity } \\
\hline Specimen & experimental & $\mathrm{Pu}$ & $\mathrm{Pu}$ & $\mathrm{Pu}, \exp$ & $\mathrm{Pu}, \exp$ \\
\hline & $\begin{array}{l}\text { ultimate load } \\
(\mathrm{Pu})(\mathrm{KN})\end{array}$ & $\begin{array}{l}, \mathrm{ACI} \\
(\mathrm{KN})\end{array}$ & $\begin{array}{l}\text {,EC2 } \\
(\mathrm{KN})\end{array}$ & $\overline{\mathrm{Pu}, \mathrm{ACI}}$ & $\overline{\mathrm{Pu}, \mathrm{EC} 2}$ \\
\hline N1-6- & 97.5 & 82.4 & - & 1.18 & - \\
\hline N2-6- & 110 & 94.13 & - & 1.17 & - \\
\hline N3-6- & 127.5 & 115.9 & - & 1.1 & - \\
\hline N1-10- & 71.5 & - & - & - & - \\
\hline N1-10- & 81.5 & - & - & - & - \\
\hline N1-10- & 118 & 108.3 & - & 1.09 & - \\
\hline ESL & 88.5 & 82.4 & 110.8 & 1.06 & 0.8 \\
\hline EGU & 120 & 86.28 & 114.8 & 1.39 & 1.04 \\
\hline $\mathrm{EFF}$ & 132.5 & 92.87 & 122 & 1.42 & 1.08 \\
\hline average & & & & 1.2 & 0.97 \\
\hline
\end{tabular}

\subsection{Mode of Failure}

For NSM group the mode of failure was steel yielding followed by flexural failure for beams 
(N1-6-165 and N2-6-165), while for beams(N36-165 and N1-10-165)the mode of failure was steel yielding followed by sudden failure by separation of CFRP bar and concrete cover at ultimate load near the location of shear crack. For EBR group the mode of failure for beam (EGU) was steel yielding followed by rupture of CFRP sheet at the mid span this occurs because the strain in FRP reaches its design rupture before the concrete reaches its maximum strain ,while the beam (ESL) was steel yielding followed by CFRP sheet bonding failure due to the rupture of L-anchorage from the bottom edge so it happened bonding failure in the CFRP strip and the beam (EFF) failed by steel yielding followed by bonding failure in the CFRP sheet at failure load.For beams (N1-10-60, N1-10-90, H1-10-60 and H1-10-90) was concrete cover separation beginning at the ends of the bonded FRP. Figure (13) shown the modes of failure of tested beams.
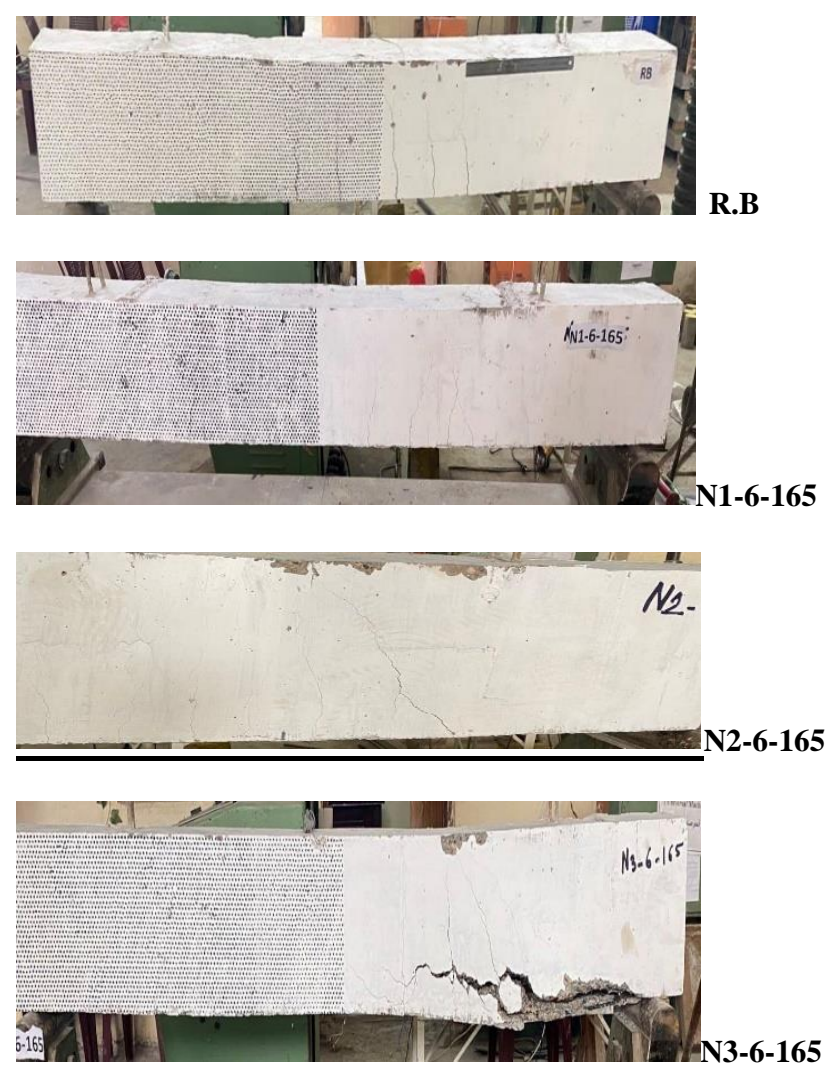
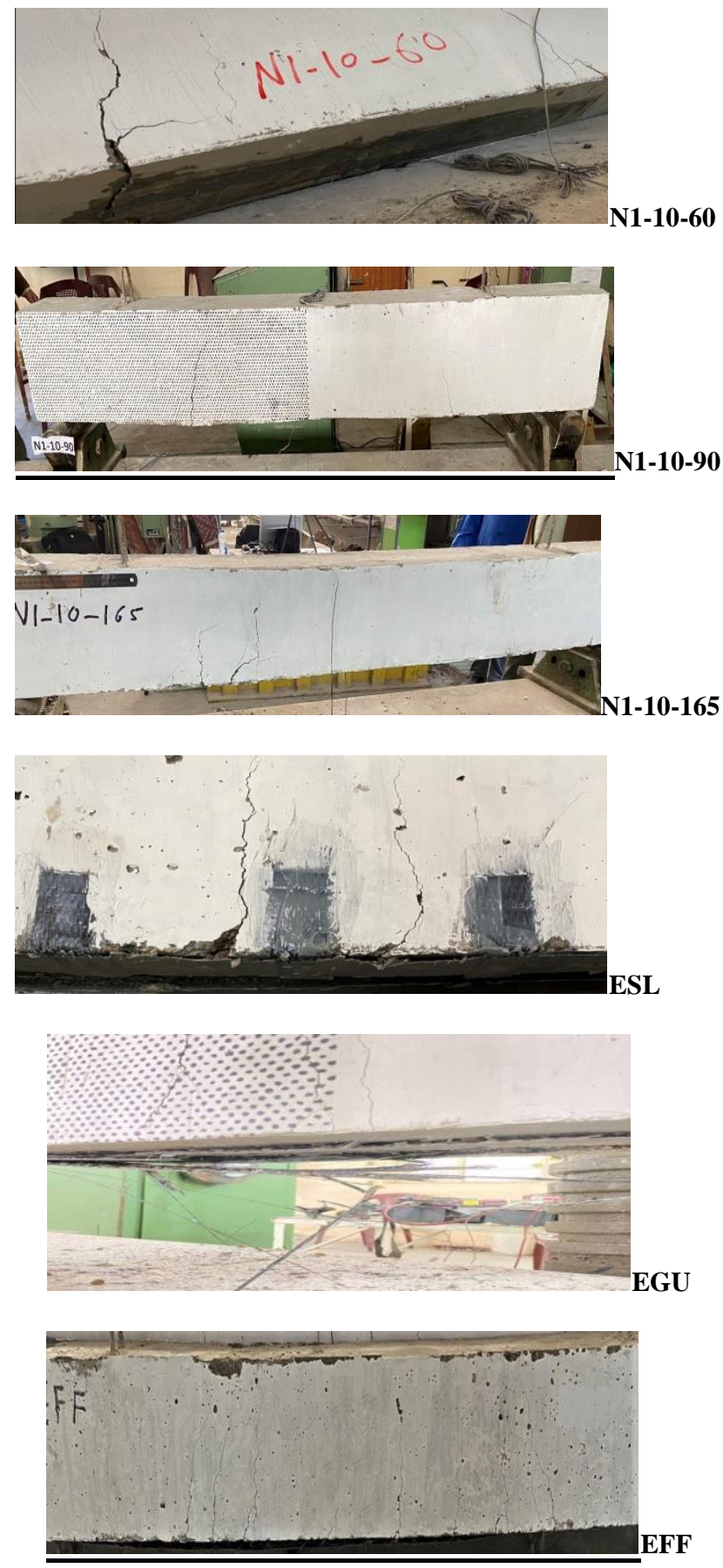

Figure 13. Failure modes

\section{Conclusions}

1. All strengthened beams showed improvement in ultimate load capacity, the increase in failure load ranging between ( 6 to $96 \%$ ).

2. The increase in the number of CFRP bar leads to increase the ultimate capacity by 
(44,63 and 89\%) for beams (N1-6-165,N26-165 and N3-6-165), respectively, as compared with reference beam which indicates that increasing the number leads to considerable improvement.

3. The increase in the length of CFRP bar leads to increase the ultimate capacity by $(6,21$ and $75 \%)$ for beams (N1-10-60,N110-90 and N1-10-165), respectively, as compared with reference beam which indicates that when using a shortest length of CFRP materials lead to marginal improvement, while when strengthened beam along the clear span, would give considerable results.

4. The results were so close for the beams which strengthened with the same area of CFRP bars (N3-6-165 and N1-10-165), so that it was preferable to use large diameter with less CFRP bars to reduce the total cost of strengthening by reducing the cost of CFRP bars, the amount of resin, and the time and effort of work.

5. The increase in the width of CFRP sheet leads to increase the ultimate capacity by (31,78 and 96\%) for beams (ESL,EGU and $\mathrm{EFF})$, respectively , as compared with the reference beam, which indicates that the increasing in the width of sheet that installed at the bottom tension face was an important factor to increase the ultimate load capacity.

6. All strengthened beams show reduction in mid-span deflection ranging between (6 to $43 \%$ ) as compared with the reference beam at same load level.

7. The strain in steel with NSM strengthening is decreased by (5 to 20\%) and for EBR strengthening the strain in steel is decreased by (34 to $86 \%$ ) at same load level.
8. Comparing failure mode, NSM with high CFRP strengthening ratio (N3-6-165 and N1-10-165) the failure mode was steel yielding followed by sudden failure by separation of CFRP bar and concrete cover at ultimate load while the beams strengthened by NSM with less CFRP reinforcement ratio the failure mode was steel yielding followed by flexural failure. For EBR the prevailing type of failure was steel yielding followed by bond failure of CFRP sheet.

9. Increasing the number and length of CFRP bars in NSM strengthening leads to reduce the crack width and spacing between cracks at all load level, also leads to increase the number of cracks after failure of beams and the same observation when the width of CFRP sheet increase in EBR strengthening.

10. The ductility index by conventional method and energy method decrease with the increase of the CFRP strengthening ratio.

11. The design provisions given by ACI440.2R-17 guidelines for NSM and EBR strengthening and EC2 guideline for EBR strengthening when compared with the results of the experimental ultimate load capacity showed that reasonable and good agreement for strengthened beams.

\section{Conflict of Interest}

The authors confirm that the publication of this article causes no conflict of interest.
Abbreviations
NSM
Near surface mounted
EBR
Externally bonded reinforcement
FRP Fiber reinforcement polymer
CFRP Carbon fiber reinforcement polymer
GFRP
$\mathrm{RC}$ 
ACI American concrete institute

EC2 Euro code

\section{References}

1. Meier, Urs. (1995). "Rehabilitation and retrofitting of existing structures through external bonding of thin carbon fiber sheets." Materials and Structures volume: 28, pp: 105-106. https://doi.org/10.1007/ BF02473179.

2. Smith, S. T. and Teng, J. G. (2002). "FRP-strengthened RC beams. I: review of debonding strength models". Engineering structures, Volume: 24, Issue: $\quad 4, \quad$ pp: $385-395$. https://doi.org/10.1016/S0141-296(01) 00105-5.

3. WU, Z., and KUROKAWA, T. (2002). "Strengthening effects and effective anchorage method for flexure members with externally bonded CFRP plates". Doboku Gakkai Ronbunshu, Volume: 711, $\quad$ pp: 1-13. https://doi.org/10.2208/jscej.2002.711_1.

4. Gopinath, S., Murthy, A. R., \& Patrawala, H. (2016). "Near surface mounted strengthening of RC beams using basalt fiber reinforced polymer bars". Construction and Building Materials, Volume: 111, pp: 1-8. https://doi.org/10.10 16/j.conbuildmat.2016.02.046.

5. Tsai, Stephen W., and H. Thomas Hahn. (1980). "Introduction to composite materials". CRC Press, Lancaster, Volume 1.

6. Mohammed, D. H. (2007). "Behavior of reinforced concrete beams strengthened by cfrp in flexure". Doctoral dissertation. $\mathrm{Ph}$. D. Thesis, University of Technology, Iraq.
7. Husain, H. M., Al-Oukaili, N. K., and ALI, D. D. (2009). "Experimental investigation of reinforced concrete flexural beams strengthened or repaired with CFRP". Journal of Engineering, Volume 15, Issue 3, pp: 3891 -3906. https://www.iasj.net/iasj/ article/24225.

8. Attari, N., Amziane, S., and Chemrouk, M. (2012). "Flexural strengthening of concrete beams using CFRP, GFRP and hybrid FRP sheets". Construction and Building Materials, Volume 37, pp: 746757.

https:

//doi.org/10.1016/j.conbuildmat.2012.07. 052.

9. Hameed, Bayda M., Husain Khalaf Jarallah, and Mithaq A. Louis., (2013). "Load-deflection behavior of reinforced concrete beams strengthened with CFRP sheets." Journal of Engineering and Sustainable Development Volume 17, Issue 4, pp: 14-26. https://www.iasj.net/ iasj/article/81355.

10. Teng, J. G., De Lorenzis, L., Wang, B., Li, R., Wong, T. N., and Lam, L. (2006). "Debonding failures of $R C$ beams strengthened with near surface mounted CFRP strips". Journal of composites for construction, Volume 10, Issue 2, pp: 92105. https://doi.org/10.1061/(ASCE)109 0-0268(2006)10:2(92).

11. El-Gamal, S. E., Al-Nuaimi, A., AlSaidy, A., and Al-Lawati, A., (2016). "Efficiency of near surface mounted technique using fiber reinforced polymers for the flexural strengthening of $R C$ beams". Construction and Building Materials, Volume 118, pp: 52-62. https://doi.org/10.1016/j.conbuildm at.2016.04152.

12. Hosen, M., Jumaat, M. Z., Alengaram, U. J., Islam, A. B. M., and Bin Hashim, H. (2016). "Near surface mounted 
composites for flexural strengthening of reinforced concrete beams". Polymers, Volume 8, Issue 3, pp: 67. https://doi. org/10.3390/ polym8030067.

13. El- Shafiey, T. F., Etman, E., Hussein, M., and El-Bosiely, M. M., (2017)."Behavior of strengthened RC beams using different techniques under static loading", International Conference on Advances in Structural and Geotechnical Engineering (ICASGE'17).

14. Hassan, H. F., Medhlom, M. T. K., Ahmed, A. S., and Al-Dahlaki, M. H. (2020). "Flexural performance of concrete beams reinforced by GFRP bars and strengthened by CFRP sheets". Case Studies in Construction Materials, Volume 13, Article 00417. https://doi.org/10.1016/j.cscm.2020. e00417.

15. ASTM C39-14. (2014). "Standard Test Method for Compressive Strength of Cylindrical Concrete Specimens". American Society for Testing and Materials.

16. ASTM C78-02(2002). "Standard Test Method for Flexural Strength of Hydraulic-Cement Mortars". Volume: 04, pp: 6.

17. ASTM, C496/C496M-11(2011). "Standard test method for splitting tensile strength of cylindrical concrete specimens."

18. Thanasis Triantafillou, Stijn Matthys, Katrien Audenaert, György Balázs, Michael Blaschko, Hendrik Blontrock, Christoph Czaderski et al. (2002). "Externally bonded FRP reinforcement for RC structures ". International Federation for Structural Concrete (fib) as Bulletin 14.

19. Ceroni, F., and Pecce, M. (2009). "Design provisions for crack spacing and width in $R C$ elements externally bonded with FRP". Composites Part B: Engineering, Volume: 40, issue: 1, pp: 17-28. https://doi.org/10.1

016/j.ompositesb.2008.07.004.

20. Oudah, F., and El-Hacha, R. (2012). "A new ductility model of reinforced concrete beams strengthened using fiber reinforced polymer reinforcement". Composites Part B: Engineering, Volume: 43, issue: 8, pp: 3338-3347. https://doi.org/10.1016/j.compo sitesb.2012.01.071.

21. ACI 440.2R-17. (2017). "Guide for the design and construction of externally bonded FRP systems for strengthening concrete structures". ACI Committee 440, American Concrete Institute, Michigan. 